\title{
走査型トンネル顕微鏡（STM）発光の高感度計測技術
}

\author{
上原 洋一*1・潮田 資勝 $* 2$
}

\section{Scanning Tunneling Microscope Light Emission Spectroscopy with Good Signal-to-noise Ratio}

\author{
Yoichi UEHARA*1 and Sukekatsu USHIODA*2 \\ ${ }^{* 1}$ Research Institute of Electrical Communication Tohoku University, 2-1-1 Katahira, Aoba-ku, Sendai 980-8577, Japan \\ *2National Institute for Materials Science, 1-2-1 Sengen, Tsukuba, Ibaraki 305-0047, Japan
}

(Received January 1, 2008, Accepted May 10, 2008)

\begin{abstract}
Scanning tunneling microscope (STM) light emission spectroscopy provides a powerful tool for characterization of individual nanometer scale structures on solid surfaces. However, the light to be detected is usually very weak. It is desirable to improve the intensity level for measurements with good signal-to-noise ratio. For this purpose the role that the STM tip-sample gap plays in the light emission is analyzed by the dielectric theory of STM light emission. Based on the theoretical predictions, we discuss how one can obtain strong STM light emission and problems associated with the enhancement of emission.
\end{abstract}

\section{1. はじめに}

走査型トンネル電子顕微鏡 (Scanning tunneling microscope, STM）発光は STM の試料-探針間の電子トンネルに より励起される発光である. 探針から放出されるナノサイズ のトンネル電子ビームが励起源となることから，探針直下の 試料ナノ物性が発光特性に反映されることが予想され, STM 発光計測は表面局所物性探索のための手法として期待 されている.

トンネル電子が励起し得る光のスペクトル領域に原理的な 制約は無いと思われるが, 最も高い感度で光計測が可能な可 視域で実験がなされることが大半である. 従って, この解説 に於いても可視発光計測を念頭に置くことにする.

STM 発光に関して, 表題の解説を書くように依頼を受け た. 高感度化の必要性は, STM 発光の励起トンネル電流が 小さいため, 計測すべき発光が基本的に弱いことによる.こ の表題から最初に思い浮かぶことは, 計測対象となる光 （STM 発光）の集光効率を向上させ, 検出システムの感度 を上げるとともに暗信号を低減させることである．重要な観 点であることには違いないが，これらについてはすでに別の 場所 ${ }^{1)}$ に記してあるので, 本解説では計測対象となる光を増 強することにより高感度計測に資するという観点から議論し たい，このために，第 2 節でSTM 発光理論（STM 発光の 誘電関数理論）の概説を紹介し, STM 発光の概略を解説す ると共に, STM 発光強度の指標としてアンテナ因子を導入 する.この理論の妥当性を第 3 節で議論した後, 第 4 節で は幾つかの具体な場合についてアンテナ因子を示す．この結 果に基づき, 第 5 節では STM 発光増強法と付随する問題に ついて議論する．第 6 節はまとめである.

\section{STM 発光の誘電関数理論}

この節ではトンネル電流摇らぎに基づくSTM 発光理論の

*1 東北大学電気通信研究所 ( 平 $2-1-1$ )

*2 物質 · 材料研究機構（干305-0047 茨城県つくば市千現 1-2-1）
概略を紹介する.この理論は, 電子トンネリングによる交流 電流源（発光源）励起を量子力学的に扱い，そこから放射さ れる光の伝搬をマックスウエルの方程式で古典的に計算する 半古典論である. 後述するように試料や探針の材料特性が誘 電関数として理論に取り込まれることから, STM 発光の誘 電関数理論とも呼ばれる.

位置座標 $\mathrm{x}$ の地点にある交流電流源の $\mu$ 成分 $J_{\mu}(\mathbf{x}, \omega)$ か らの放射電界 $E_{v}$ は次のマックスウエルの方程式により決定 される $(\mu, v=x, y, z)$ :

$$
\begin{aligned}
\left(\varepsilon(\omega) \frac{\omega^{2}}{c^{2}} \delta_{\mu \nu}+\right. & \left.\nabla^{2} \delta_{\mu \nu}-\frac{\partial}{\partial x_{\mu}} \frac{\partial}{\partial x_{\nu}}\right) E_{v}(\mathbf{x}, \omega) \\
& =\frac{4 \pi}{c^{2}}(-i \omega) J_{\mu}(\mathbf{x}, \omega)
\end{aligned}
$$

ここで, $\omega$ は角振動数, $\varepsilon(\omega)$ は材料の誘電関数, $\delta_{\mu \nu}$ はク ロネッカーのデルタである. 探針と試料の材料は共に等方的 かつ非磁性 $(\mu(\omega)=1)$ であると仮定されている.

STMのような複雑な構造を持つ系に対して(1)式の厳密 解を得るのは困難であり, 何らかの単純化を施した系として 解析されるか, Finite Differential Time Domain (FDTD) 法 のような手法を用いて数值解析 ${ }^{2}$ される. 以下では前者の立 場の理論を紹介する.

理論計算を可能にするために様々な単純化が提案されてい る3,4) が, ここでは探針を球, 試料を半無限の平板で模擬 し, 発光源となる交流電流源は探針一試料ギャップ間の対称 軸上にあると考える近似 ${ }^{5,6)}$ を考える．この場合，(1)式から 求められる遠距離領域での放射（Far field）強度 $P_{\mathrm{STM}}(\omega)$ は,

$$
P_{\mathrm{STM}}(\omega)=A_{\mathrm{STM}}(\omega)|I(\omega)|_{\mathrm{STM}}^{2}
$$

の形になる.ここで, $A_{\mathrm{STM}}(\omega)$ はアンテナ因子7) と呼ばれ, $|I(\omega)|_{\text {STM }}^{2}$ は発光源となる交流電流源 $J_{\mu}(\mathbf{x}, \omega)$ のパワース ペクトルである. トンネル電子により励起される発光源の特 性は $|I(\omega)|_{\text {STM }}^{2}$ 中に含まれる. そして, 観測される発光強 度 $P_{\mathrm{STM}}(\omega)$ は $|I(\omega)|_{\mathrm{STM}}^{2}$ にアンテナ因子 $A_{\mathrm{STM}}(\omega)$ を乗じ ることにより決まる.アンテナ因子が大きくなれば, 同じ $|I(\omega)|_{\text {STM }}^{2}$ に対しても, 放射は強くなる. すなわち, 試料- 
探針ギャップは一種のアンテナとして働き，アンテナの効率 を定めるのがアンテナ因子である.

アンテナ因子は，探針形状（ここで取り上げた場合では探 針を模擬する球の半径) 等の幾何学的要因と, 誘電関数を通 して考慮される試料, 探針の材料学的要因により決定され る. 言い換えれば, STM 発光特性は探針, 試料の材質や探 針形状にも大きく影響を受けることが理論的に予想され，実 際，実験的にもしばしば実感されるところである.

$\mathrm{STM}$ 発光に抢ける交流電流源 $J_{\mu}(\mathbf{x}, \omega)$ の励起機構は様 々知られている.たとえば，探針直下に光学遷移が許容され た分子 (発光性の分子) が置かれている場合には, この光学 遷移により $J_{\mu}(\mathbf{x}, \omega)$ が励起される ${ }^{8)}$. 直接遷移型の半導体 ではホールと電子の再結合により $J_{\mu}(\mathbf{x}, \omega)$ が励起される ${ }^{9)}$. しかし, STM 発光を計測手法として一般的なものとしてい るのは, 材料を選ばず交流電流源（発光源）を励起する機 構 ${ }^{10)}$ が存在することによる. それは次のようなものである.

電子トンネルは確率過程であるから, 直流バイアス下にお いても, 一個の電子がトンネルした後に次の電子がトンネル するまでの時間間隔は一定ではない。すなわち, 短い時間間 隔では，トンネル電流值は量子力学的要因により常に摇らい でいる. ハイゼンベルグ形式でのトンネル電流演算子を $\hat{I}(t)$ とすると, トンネル電流摇らぎによる $|I(\omega)|_{\text {STM }}^{2}$ は,

$$
|I(\omega)|_{\mathrm{STM}}^{2}=\int<\hat{I}(t)+\hat{I}(0)>e^{-i \omega t} d t
$$

で与えられる。ここで, $\mathrm{t}$ は時間, 〈… は統計平均を表す. エネルギーに電子状態密度（DOS）が依存しないフラット DOS を仮定し，トンネルバリアーの厚さや高さの効果が無 視出来る場合（トンネル確率がトンネル電子のエネルギーに 依存しない場合),（4)式は

$$
|I(\omega)|^{2}=e I_{\mathrm{o}}\left(1-\frac{\mathrm{h} \omega}{e V_{\mathrm{o}}}\right)
$$

となる10).ここで, $I_{\mathrm{o}}$ はトンネル電流 (の平均值), $V_{\mathrm{o}}$ は試 料, 探針間に印加したバイアス電圧, $e$ は素電荷である。な お，トンネルバリアーの厚さや高さの効果も解析されてい る7,11)が，ここでは詳細には触れない。

\section{STM 発光の誘電関数理論の妥当性}

前節で紹介したSTM 発光理論を用いて強いSTM 発光を 得るための検討を始める前に，その妥当性を示しておくこと は有用であろう．2つの事例を紹介する．Fig. 1 はタングス テン $(\mathrm{W})$ 探針, $\mathrm{Au}(110)-(2 \times 1)$ 清浄表面を試料とする STM 発光スペクトルである12). 実線が実験結果, 破線が第 2 節の理論による計算結果である. ここで, 実験曲線と理論 曲線は, 共に 1 に規格化されている. 良い一致が得られて いる.

アンテナ因子の大小が発光強度を決めるので, アンテナ因 子のサイズが正しく評価されていることを確認しておくこと も第 4 節以降の議論において重要である.このために, 構 造は全く異なるが共に電子トンネル励起発光である STM 発 光とトンネル接合 (Light emitting tunnel junction, LETJ) 発光の強度比を計算し, 実験值と比較する（絶対值の評価は 困難であるため, 相対值が正しく評価できることで妥当性を

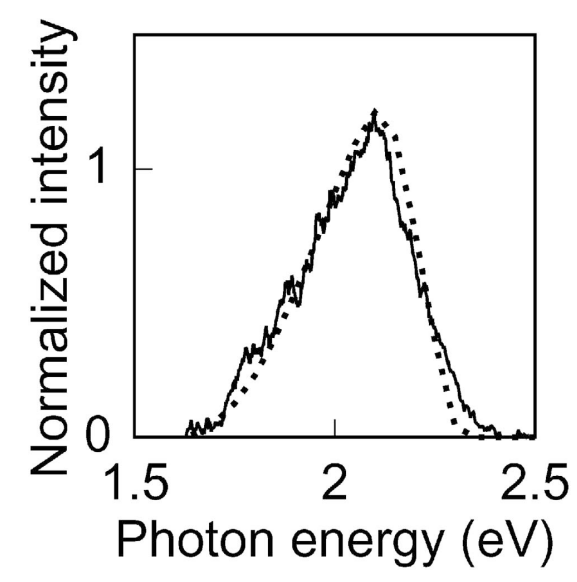

Fig. 1 The solid curve is the STM light emission spectrum of $\mathrm{Au}(110)-(2 \times 1)$ taken with a $\mathrm{W}$ tip. The dotted curve is the prediction of the theory described in the text. Both spectra are normalized to unity for comparison.

示そうという意図である). 結果を示す前に両者の歴史的関 係について簡単に触れることにする.

電子トンネル励起による可視発光は金属層-絶縁膜-金属層 (M-I-M) 構造を有する（数 $\mathrm{mm}^{2}$ 程度の面積の）平板接合 で最初に発見された ${ }^{13)}$ 。このような接合はLETJと呼ば れ，接合に印加したバイアス電压を $V_{\mathrm{o}}$ とすると，(5)式か ら期待されるように, 光子エネルギー $\hbar \omega$ が関係式

$$
\hbar \omega \leq e V_{\text {o }}
$$

を満たすスペクトル領域でブロードな発光を放射する．量 $e V_{0}$ はトンネルした電子が対向電極で持ちうる最大のエネル ギーであるから, 関係式 (6) は発光が単一電子のトンネリン グにより励起されていることを示す． $e V_{0}$ はトンネル電子励 起発光での量子カットオフと呼ばれる. LETJの発光機構に 関する研究はその発見13)直後から活発になされ，Mills ら ${ }^{14)}$ により開発されたトンネル電流摇らぎに基づく発光理論は関 係式(6)を含め観測された発光特性をよく説明15)した.これ らの理論の延長線上に第 2 節で紹介した STM 発光の理論が ある。

STM も探針（金属）一真空ギャップ（絶縁層）一試料から なる接合を有するので, M-I-M 接合と同様の機構で発光す ることが期待された. しかし，M-I-M 接合での発光計測が $\mu \mathrm{A}$ から $\mathrm{mA}$ のトンネル電流領域でなされるのに対し, $\mathrm{STM}$ に於けるトンネル電流は $\mathrm{nA}$ 領域と 3 桁以上小さくな る. 一電子励起発光であるトンネル発光の強度はトンネル電 流に比例するので, より微弱なトンネル電流で動作している STM からの電子トンネル励起発光が観測可能かどうかは自 明ではない.STMの発明から 5 年以上経過した 1988 年にな って, IBM チューリッヒの Gimzewski らのグループにより STM 発光が最初に報告された ${ }^{16)}$. 低電流にも拘らず発光が 観測されたことは, STM の放射効率が LETJのそれに比べ て格段（3 桁以上）高いことを示す. 第 2 節の理論が妥当で あれば，この違いが再現されるはずである.

STM 発光の理論が LETJ の理論を基盤にしていることか らも分かるように, LETJ からの発光もSTM 発光と同様に 表現される。（ただし，LETJに於いては平板電極からの放 
射として解析される.)

$$
P_{\text {LETJ }}(\omega)=A_{\text {LETJ }}(\omega)|I(\omega)|_{\text {LETJ }}^{2}
$$

ここで, $P_{\text {LETJ }}(\omega), A_{\text {LETJ }}(\omega),|I(\omega)|_{\text {LETJ は各々, LETJ }}^{2}$ の放射強度, アンテナ因子, トンネル電流のパワースペクト ルである.このことから, STM 発光とLETJ 発光の強度比 は

$$
\frac{P_{\mathrm{STM}}(\omega)}{P_{\mathrm{LETJ}}(\omega)}=\frac{A_{\mathrm{STM}}(\omega)}{A_{\mathrm{LETJ}}(\omega)} \cdot \frac{|I(\omega)|_{\mathrm{STM}}^{2}}{|I(\omega)|_{\mathrm{LETJ}}^{2}}
$$

と表される。（5)式から分かるように, 因子 $\frac{|I(\omega)|_{\text {STM }}^{2}}{|I(\omega)|_{\text {LETJ }}^{2}}$ は動 作電流の比と同程度であり，実験的には $10^{-3} \sim 10^{-6}$ とな る. 同等の発光強度が観測されることは $\frac{P_{\mathrm{STM}}(\omega)}{P_{\mathrm{LETJ}}(\omega)} \sim 1$ を意 味するから $\frac{A_{\mathrm{STM}}(\omega)}{A_{\mathrm{LETJ}}(\omega)}=10^{-3} \sim 10^{-6}$ である必要がある。 $A_{\text {LETJ }}(\omega)$ を決定する要因の中には LETJ の表面や界面の粗 さ (roughness) も入ってくるため, この比を簡単に求める ことはできないが，Si を試料とする STM 発光と Si-MOS 接合について評価がなされた. その結果, 可視域で $10^{3}$ 程度 の值を取ることが報告されている17).このように適切な值 が得られたことは，アンテナ因子のサイズを含め理論が妥当 であることを示すものである。

\section{4. アンテナ因子の材料依存性}

繰り返しになるが, STM 発光の誘電関数理論では STM 発光が励起源 $|I(\omega)|_{\text {STM }}^{2}$ とアンテナ因子 $A_{\mathrm{STM}}(\omega)$ の積に 分離される. 従って, トンネル電流摇らぎで励起された発光 だけではなく，いろいろな場合に適応可能である，例えば， 分子内の電子遷移に対応する $|I(\omega)|_{\mathrm{STM}}^{2}$ を理論に代入すれ ば，分子の STM 発光に対応できる. より大きなアンテナ因 子を有する探針と基板の組み合わせを選び，その基板上に目 的とする分子を吸着させれば，分子からの STM 発光はより 強くなり，高感度計測が可能になる。

アンテナ因子が大きな材料依存性を示すことを幾つかの材 料例について見てゆこう. Fig. 2 (a) は試料が共に金（Au） の場合について, 曲率半径50 $\mathrm{nm}$ の $\mathrm{W}$, 銀 $(\mathrm{Ag}), \mathrm{Au}$ 探針 のアンテナ因子を $1.5 \mathrm{eV}$ から $3.0 \mathrm{eV}$ の光子エネルギー範囲 にわたって計算したものである. 可視域での STM 発光強度 を増強するという観点からは, STM の画像計測において一 般的な $\mathrm{W}$ 探針よりも, $\mathrm{Ag}$ や $\mathrm{Au}$ 探針の方が有効であること がわかる。

探針材質と同様に，基板の材質もアンテナ因子に大きな影 響を及ぼす。Fig. 2(b) は半径50 nm の Au 探針の場合につ いて，探針材質と試料材質の異なる組み合わせに対して計算 したアンテナ因子を示す. $\mathrm{Au}$ 基板から $\mathrm{Si}$ 基板に交代する と, 同じ $\mathrm{Ag}$ 探針の場合でも $2.5 \mathrm{eV}$ 以下のスペクトル領域で アンテナ因子が極めて小さくなることがわかる．この違い

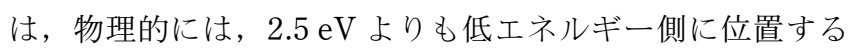
$\mathrm{Au}$ の表面プラズモン共鳴による増強が $\mathrm{Si}$ 基板では機能しな いことによる. $\mathrm{Si}$ 基板, $\mathrm{Ag}$ 探針 (Fig. 2 の標記では $\mathrm{Si} / \mathrm{Ag}$ ) 系では Ag の表面プラズモン共鳴効果により, 高光子エネル ギー側 $(3 \mathrm{eV} よ り$ 高エネルギー側に位置する表面プラズモ

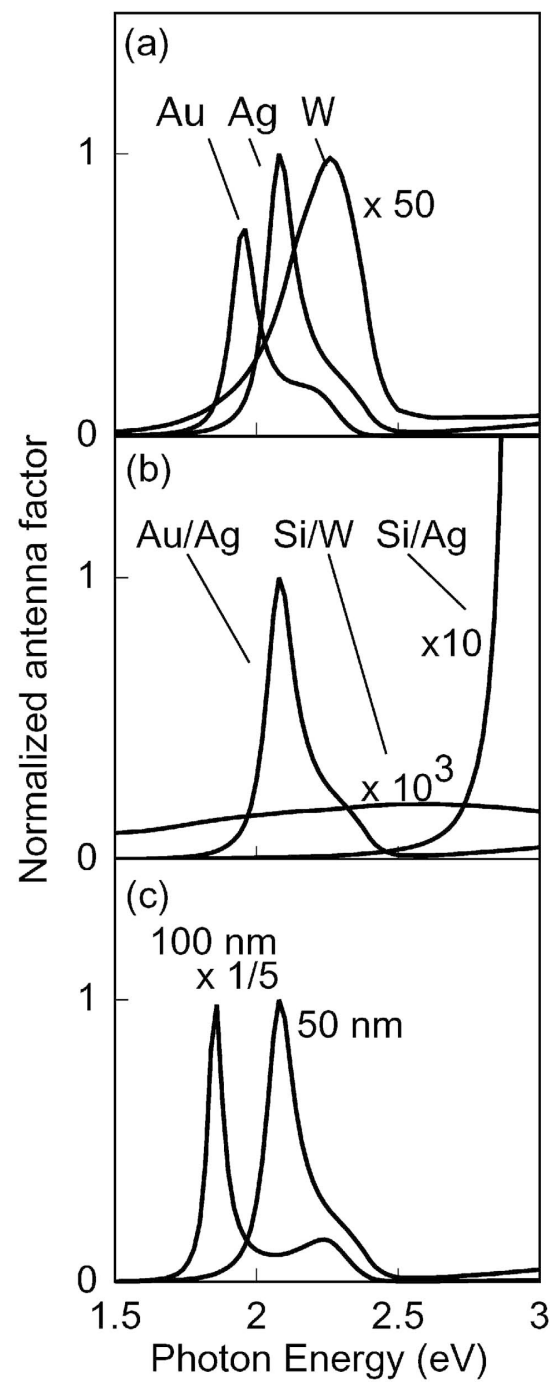

Fig. 2 (a) Antenna factors for various tip materials. The sample is Au. (b) Antenna factors for various combinations of tip and sample materials. (c) Antenna factors for the radii of tip front curvature of $50 \mathrm{~nm}$ and $100 \mathrm{~nm}$. The tip and sample materials are $\mathrm{Ag}$ and $\mathrm{Au}$, respectively.

ン共鳴）に向かってアンテナ因子が大きくなる．共鳴効果の 寄与のない $\mathrm{Si} / \mathrm{W}$ 系では, アンテナ因子は極めて小さな值に 留まる.

最後に，探針の曲率半径依存性を見てみよう. Fig. 2 (c) は $\mathrm{Ag}$ 探針- $\mathrm{Au}$ 基板の組み合わせに対するアンテナ因子スペ クトルの探針曲率依存性である. 曲率半径が大きくなるに従 い発光強度が増大する. 第 2 節で紹介した理論の枠内では アンテナ因子は曲率半径に対して単調に増加するが, 数值解 析の結果からは, それ以上の曲率半径ではアンテナ因子が逆 に小さくなってゆく上限值が存在することも知られている2).

\section{STM 発光の増強と問題点}

第 4 節では, 貴金属系の探針, 試料の組み合わせに対し て大きなアンテナ因子が得られること, 実験目的により貴金 属基板を用いることが出来ない場合でも貴金属探針の採用が STM 発光の増強に有効であることを見てきた. 貴金属探針 を利用する際の問題はアンテナ因子が強い光子エネルギー依 
存性を示すことにある。計測されるスベクトルは「計測対象 の探針直下のナノ物性をそのまま反映したもの」ではなく， アンテナ因子の影響を受けていることに注意を払わなければ ならない，特に，貴金属探針と貴金属基板を組み合わせた場 合には, 探針形状にも敏感に反応する複雑なスペクトル構造 を持つようになる (Fig. 2 (c)を参照). 従って, 観測された STM スペクトルの解釈には一層の注意を払わねばならない.

試料が貴金属でない場合に於いても，Au探針では $2 \mathrm{eV}$ 以上のスペクトル領域でアンテナ因子が小さくなることが理 論計算より予測されている。このことは, $2 \mathrm{eV}$ 以上のスペ クトル領域で精密計測を行いたい場合には Au 探針は不向き であることを意味する.最近我々のグループでは STM 発光 による振動分光 (STM 発光振動分光法) 18,19 に に興味をもっ ているが，この場合には量子カットオフ近辺の STM 発光ス ペクトル形状を正確に計測する必要がある。（我々がよく用 いている） $2.3 \mathrm{~V}$ 位のバイアス電圧に対しては, $2 \mathrm{eV}$ 以上の 光子エネルギーではアンテナ因子が小さくなる $\mathrm{Au}$ 探針は適 切でない。

以上見てきたように貴金属探針はいろいろと問題を有する が, 該当スペクトル領域で誘電損失が大きく, その結果 $\mathrm{W}$ 探針による STM 発光計測では十分な $\mathrm{S} / \mathrm{N}$ を得難い試料材 質も多く存在する．このような場合には貴金属探針が極めて 有効であることは違いない，貴金属は W に較べ遙かに柔ら かいので, 比較的高バイアス (数 $\mathrm{V}$ 程度), 高電流 (数 $\mathrm{nA}$ 程度）下で計測を行うSTM 発光では損傷しやすいと思われ るかもしれない。しかし, 我々の経験では W 探針と同様に 扱えるように思える．その作製も W 探針と同様に比較的容 易である20).

アンテナ因子の増大は探針曲率半径の増加によってももた らされるというのが理論予測であった (Fig. 2 (c) 参照). 最 後にこの予測と整合性を有する面白い実験事実 21 を紹介す る. Fig. 3(a)は作りたてのW 探針で計測した $\mathrm{Au}(110)$ 表 面のSTM 発光スペクトルの一例である. Fig. 1 のスペクト ルに比べ露光時間は $1 / 3$ と短いが, それを考慮しても極め て微弱な発光しか観測されていない，このように，STM 発 光の強度が「同じように作製した同様の構造（探針先端の曲 率半径）を持つ探針」の間でも大きく異なることが計測手法 としての STM 発光が抱える大きな問題である.

この探針を試料表面にソフトにクラッシュさせる。（クラ ッシュはフィードバックを切った状態で STM の粗動機構に より行うが，その程度を定量化して示すことができないこと を打許し願いたい。ハードに探針をクラッシュさせると STM 発光は完全に得られなくなる.）その結果, STM 発光 は, Fig. 3(b) に示すように劇的に増大する.クラッシュの 条件を押さえてしまえば，ほぼ $100 \%$ の確率で，クラッシュ させる前に観測されていた発光強度に較べ数 10 倍から数 100 倍の増大を起こすことができる. クラッシュは Au 基板表面 に対して行うが, 得られた強いSTM 発光は試料材質を選ぶ ことなく観測されるようになる.

この現象を理論面から考察してみよう. ソフトクラッシュ の結果, 探針曲率は大きくなるであろう。このことは, 理論 的には, 発光強度の増大につながる (Fig. 2 (c) 参照). ま

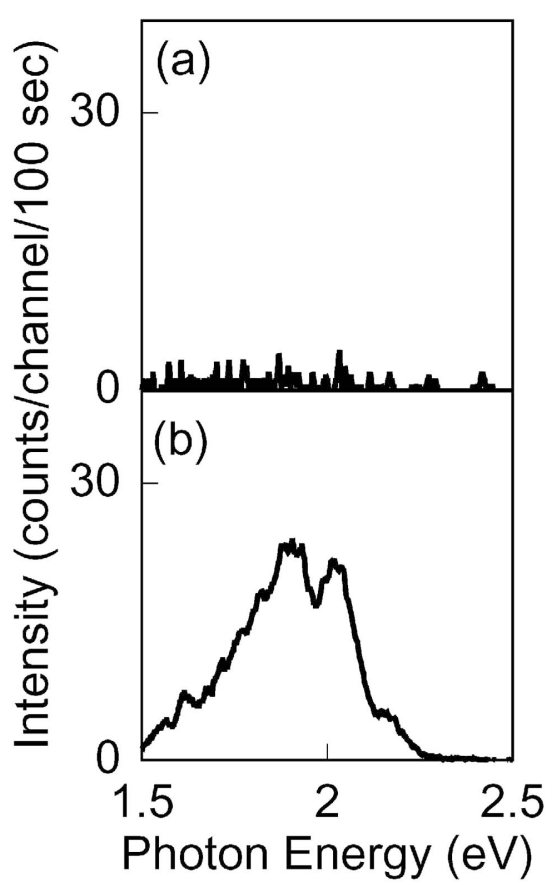

Fig. 3 (a) The STM light emission spectrum measured with an as fabricated $\mathrm{W}$ tip. The sample is $\mathrm{Au}(110)-(2 \times 1)$. (b) The STM light emission spectrum observed after the crash procedure described in the text. The light intensity after the crash became hundreds of times stronger than that of (a).

た，確認をしたわけではないが，金が探針先端に少量付着す ることもあり得ると考えている. Au 探針は W 探針に較べ て大きいアンテナ因子を有するから，クラッシュによる発光 強度の増大と理論予想の間には整合性がある.

さらに，この操作により STM 像の原子分解能が失われる こともほとんど無い. 従って, このソフトクラッシュ法は実 験目的によれば有用かつ簡単な感度増強手法であると言え る. 難点を挙げるとすれば, その結果観測されるスペクトル は，「作りたての W 探針の場合のように（例えば，Fig. 1の ように) STM 発光の誘電関数理論で再現できることはない」 ことである. 従って, 理論計算との比較から試料ナノ物性を 議論したい場合には不適切かもしれない。

\section{6. まとめ}

STM 発光計測の高感度化に関して, アンテナ因子の観点 から解説した. STMの誘電関数理論を紹介し, STM 発光 特性をよく再現しうる理論であることを示した．この理論を 基に幾つかの探針, 試料材質の組み合わせに対してアンテナ 因子を計算し，貴金属探針が高感度化に寄与しうることを紹 介した. 貴金属探針のアンテナ因子は強い光子エネルギー依 存性を示すので, 実験結果の解析には注意を払う必要がある ことにも触れた。最後に, 簡便な STM 発光強度増大法とし てソフトクラッシュ法を紹介した.

\section{〔文献〕}

1）走査型トンネル顕微鏡（STM）発光分光（実戦ナノテクノロ ジー・走査プローブ顕微鏡と局所分光, 286-302, 裳華房, 2005). 
2) Y. Uehara, Y. Suda, S. Ushioda and K. Takeuchi: Appl. Phys. Lett., 79 (2001) 1718.

3) A. Downes, M. E. Taylor and M. E. Welland: Phys. Rev. B, 57 (1998) 6706.

4) Shiwei Wu and D. L. Mills: Phys. Rev. B, 65 (2002) 205420.

5) R. W. Rendell, D. J. Scalapino and B. Muhlschlegel: Phys. Rev. Lett., 41 (1978) 1746.

6) Y. Uehara, Y. Kimura, K. Takeuchi and S. Ushioda: Jpn J. Appl. Phys., 31 (1992) 2465.

7) J. R. Kirtley, T. N. Theis, J. C. Tsang and D. J. DiMaria: Phys. Rev. B, 27 (1983) 4601.

8) Y. Uehara and S. Ushioda: Appl. Phys. Lett., 86 (2005) 181905.

9) S. F. Alvarado, Ph. Renaud and H. P. Meier: J. de Phys. IV, 1 (1991) 271.

10) D. Hone, B. Mühlschlegel and D. J. Scalapino: Appl. Phys. Lett., 33 (1978) 203.
11) Y. Uehara, J. Watanabe, S. Fujikawa and S. Ushioda: Phys. Rev. B, 51 (1995) 2229.

12) Y. Uehara, T. Fujita and S. Ushioda: Phys. Rev. Lett., 83 (1999) 2445.

13) J. Lambe and S. L. McCarthy: Phys. Rev. Lett., 37 (1976) 923.

14) B. Laks and D. L. Mills: Phys. Rev. B, 20 (1979) 4962.

15) A. Takeuchi, J. Watanabe, Y. Uehara and S. Ushioda: Phys. Rev. B, 38 (1988) 12948.

16) J. H. Coombs, J. K. Gimzewski, B. Reihl, J. K. Sass and R. R. Schutter: J. Microscopy, 152 (1988) 325.

17) Y. Uehara, M. Kuwahara and S. Ushioda: Jpn. J. Applied Phys., 39 (2000) 4904.

18) Y. Uehara and S. Ushioda: Phys. Rev. Lett., 92 (2004) 066102.

19) Y. Uehara and S. Ushioda: Surf. Sci., 601 (2007) 5643.

20）例えば, M. Iwami, Y. Uehara and S. Ushioda: Rev. Sci. Instrum., 69 (1998) 4010.

21）未発表. 